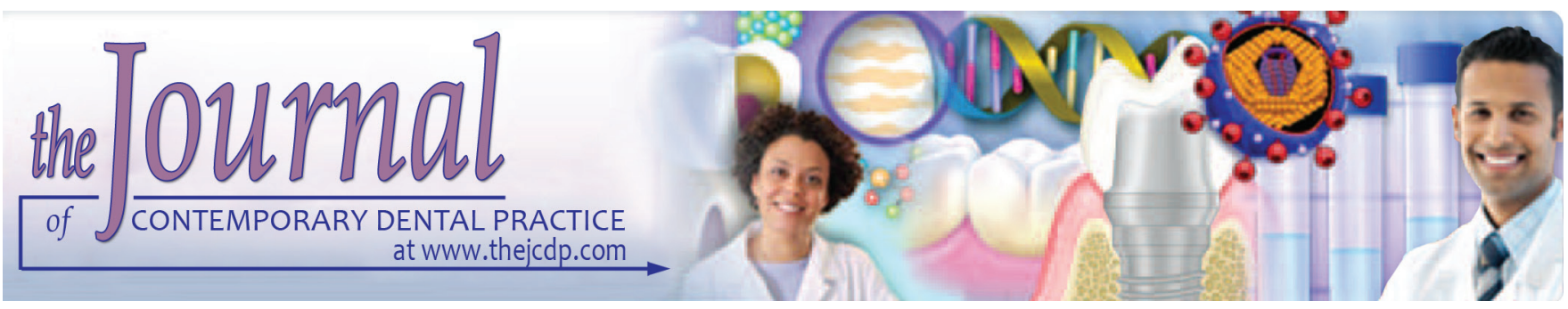

\title{
Antimicrobial Effect of Ginger, Garlic, Honey, and Lemon Extracts on Streptococcus mutans
}

\author{
${ }^{1}$ Kiran Mathai, ${ }^{2}$ Swathy Anand, ${ }^{3}$ A Aravind, ${ }^{4}$ Praveen Dinatius, ${ }^{5}$ Anandhu V Krishnan, ${ }^{6}$ Meera Mathai
}

\begin{abstract}
Aim: The aim of this study was to evaluate the effect of lemon, ginger, garlic, and honey extracts on Streptococcus mutans.

Materials and methods: Commercially obtained honey, ginger, garlic, and lemon were included in the study to evaluate its efficacy in isolation and in combination against $S$. mutans. The efficacies of extracts were tested using well diffusion method, and its effect was evaluated by measuring the zone of inhibition around the well. Antimicrobial activity of the extracts was carried out individually and compared considering triplicates of all the extracts.
\end{abstract}

Results: When individual comparison of the extracts was made, garlic showed greatest antimicrobial activity with a mean zone of inhibition $(34.9 \pm 0.58 \mathrm{~mm})$ and honey showed least antimicrobial activity $(0.5 \pm 0.6 \mathrm{~mm})$. When combinations of extracts were tested against $S$. mutans, lemon and garlic combination showed the greatest zone of inhibition $(27.6 \pm 0.43 \mathrm{~mm})$ compared with other combinations, and ginger + lemon combinations showed the least zone of inhibition $(12.6 \pm 0.43 \mathrm{~mm})$.

Conclusion: This study concluded that garlic showed a greatest antimicrobial effect against $S$. mutans when compared with other

\footnotetext{
${ }^{1}$ Department of Public Health Dentistry, St. Gregorios Dental College, Ernakulam, Kerala, India

${ }^{2}$ Department of Public Health Dentistry, Noorul Islam College of Dental Sciences, Thiruvananthapuram, Kerala, India

${ }^{3}$ Department of Public Health Dentistry, Government Dental College, Thrissur, Kerala, India

${ }^{4}$ Department of Public Health Dentistry, Century International Institute of Dental Sciences and Research Centre, Kasaragod Kerala, India

${ }^{5}$ Department of Public Health Dentistry, Azeezia College of Dental Sciences and Research, Kollam, Kerala, India

${ }^{6}$ Department of Oral Medicine \& Radiology, PMS College of Dental Science \& Research, Thiruvananthapuram, Kerala, India

Corresponding Author: Kiran Mathai, Department of Public Health Dentistry, St. Gregorios Dental College, Ernakulam Kerala, India, e-mail: drkiranmathai@gmail.com
}

preparations individually and garlic and lemon showed greatest zone of inhibition in combination than other preparations.

Clinical significance: Antibiotics and other chemical agents are mainly used to treat the common dental infections. However, due to the excessive use, it can result in antibiotic resistance. Hence, herbal medicines with medicinal values should be replaced with conventional methods.

Keywords: Dental caries, Garlic, Streptococcus mutans, Zone of inhibition.

How to cite this article: Mathai $\mathrm{K}$, Anand $\mathrm{S}$, Aravind $\mathrm{A}$, Dinatius P, Krishnan AV, Mathai M. Antimicrobial Effect of Ginger, Garlic, Honey, and Lemon Extracts on Streptococcus mutans. J Contemp Dent Pract 2017;18(11):1004-1008.

Source of support: Nil

Conflict of interest: None

\section{INTRODUCTION}

Dental caries and periodontal diseases are the major reasons for dental infections and tooth loss. Due to poor oral hygiene, dental plaque got accumulated on the tooth surface. ${ }^{1}$ Bacteria present on the plaque ferment the dietary carbohydrates and result in acid production and dissolution of dental hard tissues. ${ }^{2}$ Among the bacterial species, streptococci play significant role in the dental caries formation. ${ }^{3}$

After the eruption of teeth, within 6 to 9 months, oral cavity gets colonized by Streptococcus mutans and remains there till the teeth present. ${ }^{1}$ Various chemical agents have found to reduce the plaque formation. Chlorhexidine is considered to have more antiplaque properties than other antimicrobial agents, but it causes brownish discoloration of the teeth and restorations. ${ }^{4}$

Antibiotics such as penicillin and vancomycin are found to have good anticaries effect, yet make changes in the oral and intestinal flora, and their regular use can result in antibiotic resistance. ${ }^{5,6}$ For thousands of years, people are using herbal medicines for the prevention and treatment of various diseases. ${ }^{7,8}$ 
Garlic (Allium sativum) is used for treating various diseases. Allicin is the main component of garlic. It is obtained by crushing the garlic clove. ${ }^{9}$ It has antioxidant properties and also protects the human body from various diseases. $^{10}$

Ginger (Zingiber) is a member of Zingiberaceae family. It is used for treating various ailments and also it has anti-inflammatory, antioxidative, and antimicrobial properties. ${ }^{11}$

Honey is a natural product composed mainly of fructose and glucose. It is used as a traditional medicine for centuries. Honey was found to possess bactericidal activity against wide variety of microorganisms. ${ }^{12}$

Lemon belongs to the family of Rutaceae. It is used to treat infections, and it also has antioxidant and astringent properties. ${ }^{13}$

With the above background, the present study was undertaken to evaluate the antibacterial effect of lemon, ginger, garlic, and honey extracts on S. mutans.

\section{MATERIALS AND METHODS}

The present study was conducted in the Department of Oral Pathology and Microbiology, Coorg Institute of Dental Sciences, Virajpet. Ethical approval of the study was obtained from the Institutional Review Board.

\section{Bacterial Strains and Culture Conditions}

Streptococcus mutans Microbial type culture collection 497 culture was subcultured in mitis salivarius (MS) agar and was anaerobically incubated at $37^{\circ} \mathrm{C}$ for 48 hours.

\section{Preparation of Solutions}

Commercially available honey, ginger, garlic, and lemon were included in the study. Its efficiency is tested in isolation and in combination against S. mutans. Honey was used in its raw form, whereas ginger and garlic were crushed into a paste using mortar and pestle and the essence of the same was obtained by squeezing the paste using a sterilized mouth mask. The surface of the lemon was sterilized using $70 \%$ alcohol, and extract was collected using a sterile needle. The $100 \%$ concentrations of all the prepared extracts were used for the research purpose.

\section{Antimicrobial Effect of Extracts against $S$. mutans}

To test the efficacies of the extracts, well-diffusion method was used and its effect was assessed by measuring the zone of inhibition around the well. Mitis salivarius agar plates were made, and S. mutans colonies adjusted to McFarland standard (0.5) were swabbed onto the plates.

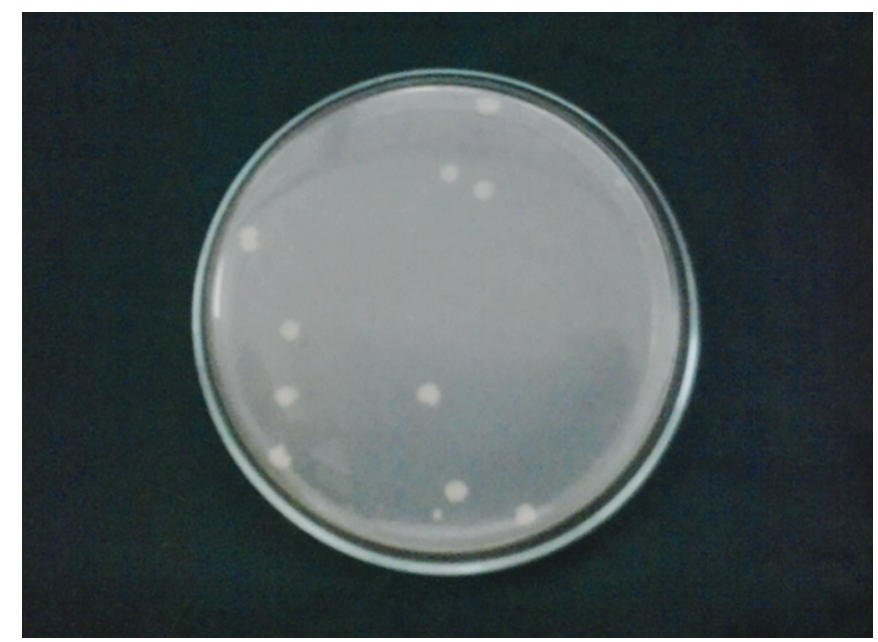

Fig. 1: Zone of inhibition of S. mutans

Using a cork borer, well of $8 \mathrm{~mm}$ was created. Each $50 \mu \mathrm{L}$ freshly prepared extract was pipetted using a micropipette and was added to the well. Then, the plates were anaerobically incubated for 24 to 48 hours using an anaerobic jar, and the zone around the well was measured (Fig. 1).

Antimicrobial activity of the extracts was carried out individually and compared by considering triplicates of all the extracts. Depending on the results obtained, the effect of combination of the extracts was performed and analyzed.

\section{RESULTS}

\section{Antimicrobial Activity of S. mutans}

The effect of all extracts was evaluated individually against $S$. mutans using the well diffusion method and then compared.

When extracts were compared, individual garlic showed greatest antimicrobial activity with a mean zone of inhibition $(34.9 \pm 0.58 \mathrm{~mm})$ and honey showed least antimicrobial activity $(0.5 \pm 0.6 \mathrm{~mm}$; Table 1$)$.

Depending on the above-obtained results, in which honey did not show significant antimicrobial activity, combinations were made between lemon, garlic, and

Table 1: Mean zone of inhibition observed by the different extracts at 48 hours

\begin{tabular}{llll}
\hline Extracts & $n$ & $\begin{array}{l}\text { Mean } \pm \text { standard } \\
\text { deviation }\end{array}$ & $\begin{array}{l}\text { Standard } \\
\text { error }\end{array}$ \\
\hline Garlic & 9 & $34.9444 \pm 0.58333$ & 0.19444 \\
Honey & 9 & $0.5556 \pm 0.58333$ & 0.19444 \\
Ginger & 9 & $11.7222 \pm 0.61802$ & 0.20601 \\
Lemon & 9 & $27.8889 \pm 1.19315$ & 0.39772 \\
Ginger + garlic + lemon & 9 & $17.9444 \pm 0.46398$ & 0.15466 \\
Garlic + ginger & 9 & $23.8889 \pm 0.33333$ & 0.11111 \\
Garlic + lemon & 9 & $27.6667 \pm 0.43301$ & 0.14434 \\
Ginger + lemon & 9 & $12.6667 \pm 0.43301$ & 0.14434 \\
\hline
\end{tabular}


Table 2: Comparison of zone of inhibition among extracts using ANOVA

\begin{tabular}{llllll}
\hline & Sum of squares & Df & Mean square & $f$-value & Significance \\
\hline Between groups & $7,768.413$ & 7 & $1,109.773$ & $2,785.313$ & 0 \\
Within groups & 25.500 & 64 & 0.398 & & \\
\hline Total & $7,793.913$ & 71 & & & \\
\hline Df: Degree of freedom & & & & \\
\hline
\end{tabular}

Table 3: Within-group comparison between different extracts using Tukey's post hoc test

\begin{tabular}{|c|c|c|c|c|}
\hline Extract & Compared with & $\begin{array}{l}\text { Mean } \\
\text { difference } \\
(I-J)\end{array}$ & $\begin{array}{l}\text { Standard } \\
\text { error }\end{array}$ & Significance \\
\hline \multirow[t]{7}{*}{ Garlic } & Honey & $34.38889^{*}$ & 0.29756 & 0 \\
\hline & Ginger & 23.22222* & 0.29756 & 0 \\
\hline & Lemon & $7.05556^{*}$ & 0.29756 & 0 \\
\hline & Gin + gar + lem & $17.00000^{*}$ & 0.29756 & 0 \\
\hline & Gin + gar & $11.05556^{*}$ & 0.29756 & 0 \\
\hline & Gar + lem & $7.27778^{*}$ & 0.29756 & 0 \\
\hline & Gin + lem & $22.27778^{*}$ & 0.29756 & 0 \\
\hline \multirow[t]{7}{*}{ Honey } & Garlic & $-34.38889^{*}$ & 0.29756 & 0 \\
\hline & Ginger & $-11.16667^{*}$ & 0.29756 & 0 \\
\hline & Lemon & $-27.33333^{*}$ & 0.29756 & 0 \\
\hline & Gin + gar + lem & $-17.38889^{*}$ & 0.29756 & 0 \\
\hline & Gin + gar & $-23.33333^{*}$ & 0.29756 & 0 \\
\hline & Gar + lem & $-27.11111^{*}$ & 0.29756 & 0 \\
\hline & Gin + lem & $-12.11111^{*}$ & 0.29756 & 0 \\
\hline \multirow[t]{7}{*}{ Ginger } & Garlic & $-23.22222^{*}$ & 0.29756 & 0 \\
\hline & Honey & $11.16667^{*}$ & 0.29756 & 0 \\
\hline & Lemon & $-16.16667^{*}$ & 0.29756 & 0 \\
\hline & Gin + gar + lem & $-6.22222^{*}$ & 0.29756 & 0 \\
\hline & Gin + gar & $-12.16667^{*}$ & 0.29756 & 0 \\
\hline & Gar + lem & $-15.94444^{*}$ & 0.29756 & 0 \\
\hline & Gin + lem & $-0.94444^{*}$ & 0.29756 & 0.045 \\
\hline \multirow[t]{7}{*}{ Lemon } & Garlic & $-7.05556^{*}$ & 0.29756 & 0 \\
\hline & Honey & $27.33333^{*}$ & 0.29756 & 0 \\
\hline & Ginger & $16.16667^{*}$ & 0.29756 & 0 \\
\hline & Gin + gar + lem & $9.94444^{*}$ & 0.29756 & 0 \\
\hline & Gin + gar & $4.00000^{*}$ & 0.29756 & 0 \\
\hline & Gar + lem & 0.22222 & 0.29756 & 0.995 \\
\hline & Gin + lem & $15.22222^{*}$ & 0.29756 & 0 \\
\hline
\end{tabular}

*Statistically significant

ginger and its effect was tested against $S$. mutans using well diffusion method.

When combinations of extracts were tested against S. mutans, lemon and garlic combination showed greatest zone of inhibition $(27.6 \pm 0.43 \mathrm{~mm})$ compared with other combinations, and ginger + lemon combinations showed least zone of inhibition (12.6 $\pm 0.43 \mathrm{~mm}$; Table 1$)$.

Analysis of variance (ANOVA) was used to compare the difference in the antimicrobial effect between and within the groups, and the result was found to be statistically highly significant ( $\mathrm{p}=0.000$; Table 2$)$.

Table 3 shows the comparison of individual preparations with other groups. The individual preparations of garlic, ginger, and honey showed a statistically highly significant $(p=0.000)$ difference between the groups, whereas lemon did not show any statistical difference
Table 4: Comparison between combinations using Tukey's post hoc test

\begin{tabular}{|c|c|c|c|c|}
\hline Extract & $\begin{array}{l}\text { Compared } \\
\text { with }\end{array}$ & $\begin{array}{l}\text { Mean } \\
\text { difference } \\
(I-J)\end{array}$ & $\begin{array}{l}\text { Standard } \\
\text { error }\end{array}$ & Significance \\
\hline \multirow{7}{*}{$\begin{array}{l}\text { Ginger + } \\
\text { garlic + } \\
\text { lemon }\end{array}$} & Garlic & $-17.00000^{*}$ & 0.29756 & 0 \\
\hline & Honey & $17.38889^{*}$ & 0.29756 & 0 \\
\hline & Ginger & $6.22222^{*}$ & 0.29756 & 0 \\
\hline & Lemon & $-9.94444^{*}$ & 0.29756 & 0 \\
\hline & Gin + gar & $-5.94444^{*}$ & 0.29756 & 0 \\
\hline & Gar + lem & $-9.72222^{*}$ & 0.29756 & 0 \\
\hline & Gin + lem & $5.27778^{*}$ & 0.29756 & 0 \\
\hline \multirow{7}{*}{$\begin{array}{l}\text { Garlic + } \\
\text { ginger }\end{array}$} & Garlic & $-11.05556^{*}$ & 0.29756 & 0 \\
\hline & Honey & $23.33333^{*}$ & 0.29756 & 0 \\
\hline & Ginger & $12.16667^{*}$ & 0.29756 & 0 \\
\hline & Lemon & $-4.00000^{*}$ & 0.29756 & 0 \\
\hline & $\begin{array}{l}\text { Gin + gar + } \\
\text { lem }\end{array}$ & $5.94444^{*}$ & 0.29756 & 0 \\
\hline & Gar + lem & $-3.77778^{*}$ & 0.29756 & 0 \\
\hline & Gin + lem & $11.22222^{*}$ & 0.29756 & 0 \\
\hline \multirow{7}{*}{$\begin{array}{l}\text { Garlic + } \\
\text { lemon }\end{array}$} & Garlic & $-7.27778^{*}$ & 0.29756 & 0 \\
\hline & Honey & $27.11111^{*}$ & 0.29756 & 0 \\
\hline & Ginger & $15.94444^{*}$ & 0.29756 & 0 \\
\hline & Lemon & -0.22222 & 0.29756 & 0.995 \\
\hline & $\begin{array}{l}\text { Gin + gar + } \\
\text { lem }\end{array}$ & $9.72222^{*}$ & 0.29756 & 0 \\
\hline & Gin + gar & $3.77778^{*}$ & 0.29756 & 0 \\
\hline & Gin + lem & $15.00000^{*}$ & 0.29756 & 0 \\
\hline \multirow{7}{*}{$\begin{array}{l}\text { Ginger + } \\
\text { lemon }\end{array}$} & Garlic & $-22.27778^{*}$ & 0.29756 & 0 \\
\hline & Honey & $12.11111^{*}$ & 0.29756 & 0 \\
\hline & Ginger & $0.94444^{*}$ & 0.29756 & 0.045 \\
\hline & Lemon & $-15.22222^{*}$ & 0.29756 & 0 \\
\hline & $\begin{array}{l}\text { Gin + gar + } \\
\text { lem }\end{array}$ & $-5.27778^{*}$ & 0.29756 & 0 \\
\hline & Gin + gar & $-11.22222^{*}$ & 0.29756 & 0 \\
\hline & Gar + lem & $-15.00000^{*}$ & 0.29756 & 0 \\
\hline
\end{tabular}

*Statistically significant

( $p=0.995)$ when compared with combinations of garlic and lemon. When the combinations were compared, all the combinations showed a statistically highly significance $(p=0.000)$ except garlic + lemon combinations which did not showed a significant difference $(p=0.995)$ when compared with lemon (Table 4).

\section{DISCUSSION}

Streptococcus mutans, a member of viridans streptococci, is the main etiological agent in the causation of dental caries. ${ }^{1}$ The studies have shown that during the period of "window of infectivity," these S. mutans get transferred from mother to child resulting in more caries-prone teeth in children. ${ }^{14}$ 
Antibiotic therapy is the conventional method of treatment for bacterial infections. However, few S. mutans have started to show resistance to these antibiotics. ${ }^{1}$

Herbal medicines have been used for the treatment of various ailments. According to the World Health Organization, majority of human population depends on herbal medicines for disease treatment and health maintenance. ${ }^{15}$

The present study was done to assess the antimicrobial effect of extracts of lemon, ginger, garlic, and honey on S. mutans.

In the present study, garlic showed the greatest zone of inhibition $(34.9 \pm 0.58 \mathrm{~mm})$ compared with the other extracts. This finding is almost similar to a study done by Jain et $\mathrm{al}^{16}$ which showed a zone of inhibition (22-44 mm) compared with the study done by Karuppiah and Rajaram. ${ }^{17}$

Honey showed the least zone of inhibition $(0.5 \pm$ $0.6 \mathrm{~mm}$ ). This may be due to the fact that we used the $100 \%$ concentration of honey and did not use any dilution. This might have prevented the penetration of honey into the agar plates. However, this result is in contrast to a study done by Ghabanchi et $\mathrm{al}^{18}$ which showed an inhibition of $13 \mathrm{~mm}$ with undiluted honey.

In the present study, ginger showed a zone of inhibition $(11.7 \pm 0.6 \mathrm{~mm})$, which is in contrast to a study done by Premkishore et $\mathrm{al}^{19}$ which showed a zone of inhibition $(20 \pm 0.7 \mathrm{~mm})$.

Our study showed a zone of inhibition $(27 \mathrm{~mm}$ ) for lemon which is in contrast to a study done by Krumina et $\mathrm{al}^{20}$ which showed a zone of inhibition of $14 \mathrm{~mm}$ for lemon extract.

Among the extracts, garlic showed the greater zone of inhibition against $S$. mutans.

Allicin is the main antibacterial agent present in the garlic. It is effective against wide variety of Gram-positive and Gram-negative bacteria. Medicinal effect of garlic is due to its sulfur compounds. ${ }^{21}$

Among the combinations, lemon and garlic combination showed the greatest zone of inhibition (27.6 \pm $0.43 \mathrm{~mm}$ ) which was slightly higher to a study done by Owhe-Ureghe et $\mathrm{al}^{22}$ which showed a zone of inhibition of $23 \mathrm{~mm}$.

\section{CONCLUSION}

Our study concluded that garlic showed a greatest antimicrobial effect against $S$. mutans when compared with other preparations individually and garlic and lemon showed the greatest zone of inhibition in combinations than other preparations. Thus, this study strongly suggests the use of garlic and lemon extracts on preparations of mouthwashes and tooth paste for the prevention of dental caries. To strengthen the use of such agents, further in vivo studies and clinical trials are recommended.

\section{REFERENCES}

1. Karikalan S, Mohankumar A. Studies on ampicillin resistant plasmid of Streptococcus mutans isolated from dental caries patients. Biotechnol Res Commun 2016 Mar;9(1):151-156.

2. Yadav K, Prakash S. Dental caries: a review. Asian J Biomed Pharm Sci 2016 Jan;6(53):1-7.

3. Nanda J, Sachdev V, Sandhu M, Deep-Singh-Nanda K. Correlation between dental caries experience and mutans streptococci counts using saliva and plaque as microbial risk indicators in 3-8 year old children. A cross sectional study. J Clin Exp Dent 2015 Feb;7(1):e114-e118.

4. Sajjan P, Laxminarayan N, Kar PP, Sajjanar M. Chlorhexidine as an antimicrobial agent in dentistry. A review. Oral Health Dent Manag 2016; 15(2): 93-100.

5. Ahmed SI, Sudhir KM, Reddy VC, Kumar RV, Srinivasulu G. Green tea in the prevention of dental caries - a systematic review. Int Arch Biomed Clin Res 2017 Jan-Mar;3(1):1-6.

6. Jafer M, Patil S, Hosmani J, Bhandi SH, Chalisserry EP, Anil S. Chemical plaque control strategies in the prevention of biofilm-associated oral diseases. J Contemp Dent Pract 2016 Apr;17(4):337-343.

7. Rakotoarivelo NH, Rakotoarivony F, Ramarosandratana AV, Jeannoda VH, Kuhlman AR, Randrianasolo A, Bussmann RW. Medicinal plants used to treat the most frequent diseases encountered in Ambalabe rural community, Eastern Madagascar. J Ethnobiol Ethnomed 2015 Sep;11:68.

8. Tulunay M, Aypak C, Yikilkan H, Gorpelioglu S. Herbal medicine use among patients with chronic diseases. J Intercult Ethnopharmacol 2015 Jul-Sep;4(3):217-220.

9. Rahman MM, Fazlic V, Saad NW. Antioxidant properties of raw garlic (Allium sativum) extract. Int Food Res J 2012 Jan;19(2):589-591.

10. Gebreyohannes G, Gebreyohannes M. Medicinal values of garlic: a review. Int J Med Med Sci 2013 Sep;5(9):401-408.

11. Mashhadi NS, Ghiasvand R, Askari G, Hariri M, Darvishi L, Mofid MR. Anti-oxidative and anti-inflammatory effects of ginger in health and physical activity: review of current evidence. Int J Prev Med 2013 Apr;4(Suppl 1):S36-S42.

12. Eteraf-Oskouei T, Najafi M. Traditional and modern uses of natural honey in human diseases: a review. Iran J Basic Med Sci 2013 Jun;16(6):731-742.

13. Oguwike FN, Onubueze DP. Evaluation of efficacy of lemon juice extract (Citrius lemoni Risso) on wound healing and haemostatic mechanism of albino Wister rats. Int J Sci Res 2013 Sep;2(9):190-193.

14. Holbrook WP, Magnúsdóttir MO. Studies on strains of Streptococcus mutans isolated from caries-active and caries-free individuals in Iceland. J Oral Microbiol 2012 Mar;4.

15. Chikezie PC, Ojiako OA. Herbal medicine: yesterday, today and tomorrow. Altern Integr Med 2015 Aug;4:195.

16. Jain I, Jain P, Bisht D, Sharma A, Srivastava B, Gupta N. Comparative evaluation of antibacterial efficacy of six Indian plant extracts against Streptococcus mutans. J Clin Diagn Res 2015 Feb;9(2):ZC50-ZC53.

17. Karuppiah P, Rajaram S. Antibacterial effect of Allium sativum cloves and Zingiber officinale rhizomes against multiple-drug 
resistant clinical pathogens. Asian Pac J Trop Biomed 2012 Aug;2(8):597-601.

18. Ghabanchi J, Bazargani A, Afkar MD, Foroushan SB, Aein SD. In vitro assessment of anti-Streptococcus mutans potential of honey. Iran Red Crescent Med J 2010 Jan;12(1):61-64.

19. Premkishore K, Umapathy T, Kathariya MD, Agrawal A, Pavan Kumar PS, Kallampilly G. Effect of honey and aqueous ginger extract against Streptococcus mutans isolated from extracted carious deciduous teeth. J Indian Acad Oral Med Radiol 2013 Oct-Dec;25(4):265-267.
20. Krumina G, Ratkevicha L, Nikolajeva V, Babarikina A, Babarykin D. Influence of plant extracts on the growth of oral pathogens Streptococcus mutans and Candida albicans in vitro. Proc Estonian Acad Sci 2015 Mar;64(1):62-67.

21. Bayan L, Koulivand PH, Gorji A. Garlic: a review of potential therapeutic effects. Avicenna J Phytomed 2014 Jan-Feb; $4(1): 1-14$.

22. Owhe-Ureghe UB, Ehwarieme DA, Eboh DO. Antibacterial activity of garlic and lime extracts on isolates of extracted carious teeth. Afr J Biotech 2010 May;9(21):3163-3166. 